\title{
Influence of crucible material on the level of contamination in TiAl using induction melting
}

\author{
J. J. Barbosa ${ }^{\dagger}$ and C. Silva Ribeiro ${ }^{\ddagger *}$ \\ ${ }^{\dagger}$ Departamento de Engenharia Mecânica, Universidade do Minho, Guimarães, Portugal \\ ${ }^{\ddagger}$ Departamento de Eng. Metalúrgica e de Materiais, FEUP, Porto, Portugal
}

This paper describes the processing results of TiAl alloys melted in a controlled atmosphere induction furnace, using crucibles made of graphite, calcia and zirconia stabilized with yttria, calcia and magnesia. Samples were poured into graphite permanent moulds or solidified and cooled inside the crucible, in order to simulate the worst case scenario in a metal/ refractory reaction using this process. This paper presents segregation profiles of residual elements and their influence on the micro hardness of different phases and the extent of the "alpha-case".

Keywords: TiAl, induction melting, crucible

\section{Introduction}

Foundry processing is one of the technologies available to process titanium alloys. Its use presents some drawbacks from the alloy itself, among which might be emphasised the high reactivity with a large number of elements (solid, liquid or gaseous) above $500^{\circ} \mathrm{C}$, with particular emphasis on oxygen. ${ }^{1}$

One of the foundry processes which shows a high potential is induction melting; processing the melt under controlled atmosphere using suitable ceramic crucibles, and investment casting. Comparing this procedure with an alternative, such as arc skull melting, the previous method presents some of the following advantages:

- Lower capital investment costs;

- A smaller area in which to set up the equipment;

- Easier temperature control;

- Easier operation;

- Melt stock is easy to prepare and the cost is lower.

The high reactivity of titanium alloys could impair the quality of castings made using crucible induction melting, due to reaction between the melt and the ceramic materials. During melting, reactions between the melt and the crucible material may occur; during pouring, between the liquid metal and the moulding material and, after solidification, between the solid alloy and the moulding material. There is also the possibility of reaction between the melt and the atmosphere of the melting chamber.

\footnotetext{
*Author for correspondence

e-mail: sribeiro@fe.up.pt
}

These reactions could contaminate the castings, due to the absorption of some residual elements, and produce chemical heterogenities, inclusions and structural variations.

This paper describes the work done with titanium aluminides prepared from pure aluminium and titanium melting stock. The main objectives were two fold:

$1^{\text {st }}$ Evaluation of the behaviour of some refractory materials during the melting of TiAl;

$2^{\text {nd }}$ The relationship between micro-hardness, the concentration profile of residual elements in those phases present at room temperature, and the extent of the "alpha-case"' (a surface layer with an higher microhardness than the average value found in the bulk of the casting).

The introduction of residual elements comes from the reduction of oxides from the crucible, which have reacted with the melt. When the alloy is in the molten state there is a strong reaction, which results in a uniform increase in the content of residual elements due to the stirring effect of the melt, together with high diffusion rates. During solidification there is less contamination, and as a result there is a higher content of contaminant elements near the interface between the crucible and the casting, continually decreasing to a sort of plateau in which the level of contaminants is constant (beyond a certain distance from the interface).

When an investment casting process is used, oxygen is a common contaminant of these alloys, because mould ceramic oxides are less stable than those resulting from the reaction of melt components with oxygen. This element has a tendency to form an interstitial solid solution with titanium. In practice, there is a surface layer with a higher oxygen content, which some call the "alpha-case" (see Figure 1). 1,2,3,4,5,6

The extent of the alpha-case $e^{a}$ is dependent on different factors such as: ${ }^{1,2}$

- Mould material;

- The duration of contact of the ceramic with the alloy, at high temperature.

There is no reference available which gives an insight into the oxygen absorption into titanium aluminides. In commercially pure titanium, some $\operatorname{argue}^{1}$ that there is a

\footnotetext{
a The size of the alpha-case was taken as the distance from the wall to the place where microhardness assumes a constant value
} 


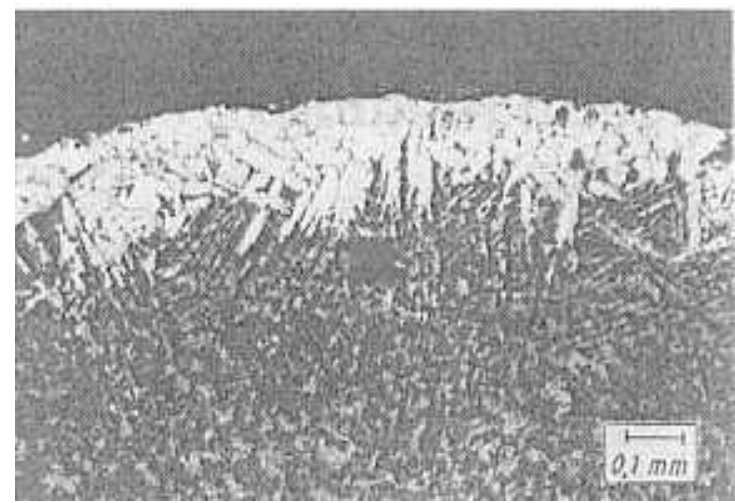

Alpha-case formation in a titanium casting [2]

possibility of oxygen enrichment from the molten state down to $500^{\circ} \mathrm{C}$. So it might be concluded that the factors which control the cooling rate are also responsible for the alpha case extent.

\section{Experimental technique}

A TiAl [Ti-48Al (at\%)] alloy has been used, prepared from pure aluminium and titanium, melted in crucibles of different materials. To evaluate the effect of a slower cooling rate upon the residual element content, the melts have been allowed to solidify and cool inside the melting crucible. Some melts have been centrifugally cast into graphite moulds, for the sake of comparison.

The results have been evaluated comparing microstructures, micro-hardness profiles and chemical composition of phases present at room temperature, using scanning microscopy and microanalysis.

\section{Process description}

During processing, a controlled atmosphere of commercially pure argon was maintained, because crucibles have been kept inside a tight sealed chamber. It was opened only when the sample was at room temperature (see Figure 2).

As can be seen, the melting crucible is held inside an

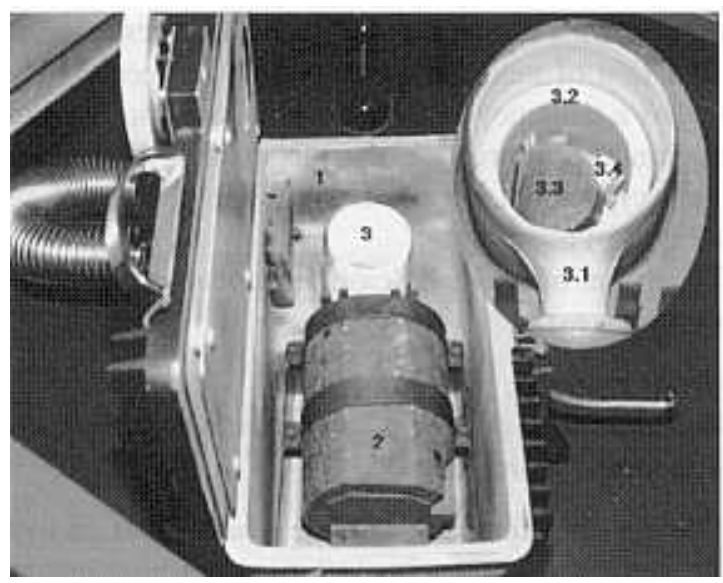

1. Furnace chamber

2. Permanent mould

3. Crucible set
3.1 Outer crúcible 3.2 Inner crucible

3.3 Titanium rod

3.4 Aluminium
Ceramic crucible induction furnace alumina support, which has a pouring lip. The purpose of this second crucible is two fold: as a coil protection in case of the primary crucible failure, and to allow a simple and easy way of pouring the melt into moulds, where necessary.

The melting procedure was as follows:

1. Positioning the melting stock in the inner crucible, in a way that the titanium lies above the aluminium (in order to get a pool of low temperature metal);

2. Drying of both inner crucible and melting stock in a muffle furnace;

3. Placing both crucibles (the outer one and the one containing the melting stock) inside the melting chamber;

4. Closing and cleaning of the melting chamber. This operation is carried out allowing the flow of commercially pure dry argon at 2.5 bar pressure for 5 minutes, after which a $2 \times 10^{-3} \mathrm{mbar}$ vacuum was applied. This procedure was applied three times before the start of the heating operation.

5. Slow heating of the melting stock up to melting, which took about 60 minutes.

6. Cooling of the alloy inside the furnace down to room temperature, after turning the power off.

The melting stock weighed about $100 \mathrm{~g}$, composed of titanium rod grade II and pure $99.8 \%$ aluminium.

Melting crucible dimensions: $\oslash 50 \mathrm{~mm} ; \mathrm{h}=75 \mathrm{~mm}$

The melt temperature was controlled with an optical pyrometer.

As is known, the temperature read with an optical pyrometer is a function of the melt emissivity. The melting procedure starts from pure components, which influenced the melt emissivity. It varied from the start of pure aluminium up to the point where the alloy was ready to be poured. When the melt reached a certain temperature, white smoke, whose origin and nature had not yet been characterized, was observed, which produced a wide variation in the temperature measurement. So it was decided to super-heat for 2 minutes after the melt reached $1500^{\circ} \mathrm{C}$, as indicated by the optical pyrometer. Furnace power and emissivity kept constant in order to have the same experimental conditions for every melt. The optical pyrometer was calibrated against a Type B thermocouple, which could be used with TiAl until $1500^{\circ} \mathrm{C}$.

\section{Crucibles}

There is no precise information on the practical use of ceramic materials to melt reactive materials. Although there are some insights, protected by patenting, ${ }^{7-14}$ no public information has been released.

It is belived that ceramic materials used in the production of melting crucibles should present some of the following characteristics:

- Higher melting temperature, well above that of the maximum alloy processing temperature;

- It should not react with the melt during processing; 


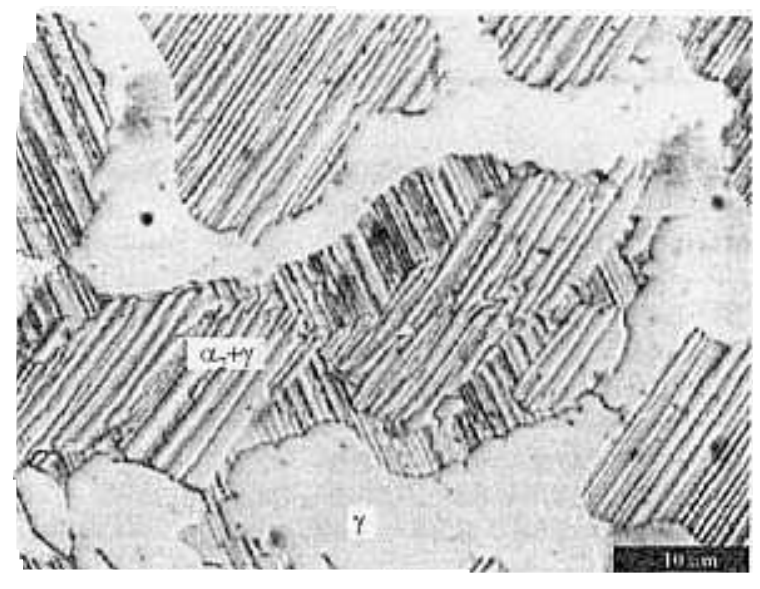

Fig. 3 Microstructure of a casting melted and cooled in a calcia stabilized zirconia crucible

- It should resist thermal shock, because the final superheating of the melt should be done very quickly, due to the high chemical reactivity of titanium alloys. This procedure produces very high thermal gradients between the part of the crucible in contact with the melt and the part which is not.

The selection of refractory materials, was made according to thermo-chemical concepts, choosing potential materials whose oxides have lower free energy for formation than titanium and aluminium oxides. Potential materials are mentioned elsewhere ${ }^{15,16,17}: \mathrm{CaO}, \mathrm{BeO}$, $\mathrm{CeO}, \mathrm{ZrO}_{2}, \mathrm{Al}_{2} \mathrm{O}_{3}, \mathrm{Y}_{2} \mathrm{O}_{3}, \mathrm{MgO}, \mathrm{HfO}_{2}$ and $\mathrm{ThO}_{2}$.

Each of these refractories has drawbacks. For instance, the low melting temperature $\left(\mathrm{Al}_{2} \mathrm{O}_{3}, \mathrm{CeO}\right)$, radioactivity $\left(\mathrm{ThO}_{2}\right)$ or the high cost $\left(\mathrm{Y}_{2} \mathrm{O}_{3}, \mathrm{HfO}_{2}, \mathrm{BeO}\right)$, reduce potential refractories to very few. ${ }^{16,17}$ The refractory materials selected were calcia $(\mathrm{CaO})$ and three types of zirconia $\left(\mathrm{ZrO}_{2}\right)$, stabilized with calcia, yttria and magnesia. Due to its low cost and high melting temperature, a few trials have been done with graphite crucibles.

Pure zirconia crucibles present some drawbacks. Zirconia presents a monoclinic structure up to about $1170^{\circ} \mathrm{C}$, tetragonal up to about $2370^{\circ} \mathrm{C}$ and cubic for higher temperatures. The transformation from monoclinic to tetragonal is believed to occur with a volume contraction of about $3 \% .^{18,19}$ This behaviour is very undesirable in crucibles. In the early trials of this material, pure zirconia monolithic crucibles were used, and all of them developed cracks.

Later, after a commercial search, $\mathrm{Y}_{2} \mathrm{O}_{3}, \mathrm{MgO}$ and $\mathrm{CaO}$ partially stabilized zirconia crucibles available from Marketec International, USA, were selected to proceed with our work.

\section{Experimental results}

Experimental results have been analysed bearing in mind

Identification of each phase and microconstituent to which a quantitative chemical analysis variation has been made using microanalysis;
- The chemical profile has been established, from the outside to the inside of the samples, in each of the microconstitients;

- The microhardness profile has been made from the outside to the inside in each of the microconstituents.

Castings produced were cylinders. In order to evaluate the structure, samples were collected from the middle of them, by sectioning the cylinders at $50 \%$ of their height.

Samples for characterization were prepared using traditional metallographic techniques: surfaces were prepared by mechanical polishing and etched with Kroll solution ( $2 \% \mathrm{HF}, 4 \% \mathrm{HNO}_{3}, 94 \% \mathrm{H}_{2} \mathrm{O}$ ).

Phase indentification and chemical composition were performed by quantitative EDS analysis with standards of pure $\mathrm{Ti}, \mathrm{Al}$ and $\mathrm{Zr}$, using a JEOL JSM 35C scanning electron microscope. A $10 \mathrm{keV}$ potential and a 100 second acquisition time were used.

As shown in Figure 3, the as cast microstructure contained two microconstituents: one with a strong dendritic pattern, with two phases $\left(\alpha_{2}+\gamma\right)$, and a $\gamma$ interdendritic phase. The dendritic constituent is present in a higher quantity in all the samples. The amount of interdendritic $\gamma$ is lower in the outside part of the samples and increases towards the inside of them, following the decrease in the cooling rate. This suggests a strong initial development of the dendritic constituent, which segregates $\mathrm{Al}$ to the melt. It is believed that the structure is the typical TiAl bi-phase structure $\left(\alpha_{2}+\gamma\right)$ in which the amount of aluminium is slightly below $49 \%$, and the amount of $\gamma$ constituent increases with an increasing $\mathrm{Al}$ content.

In all the samples, the lamellar dendritic bi-phase constituent is richer in titanium and the monophase interdendritic constituent has higher aluminium content, according to the available references. ${ }^{21}$

The samples made in zirconia crucibles present a slight variation in titanium and aluminium content inside each microsconstituent, from the outside towards the inner part of them.

In samples made in calcia crucibles, there is an increase in titanium and a decrease in aluminium content in both microconstituents, from the outside towards the inside of the casting.

In both situations the relationship between $\mathrm{Ti}$ and $\mathrm{Al}$ is kept constant, whatever the distance from the surface of the sample.

\section{Samples cooled, up to room temperature, inside the crucibles in the furnace \\ Zirconia crucibles}

The results are summarised in Table 1 and all comments are based upon it.

Samples processed in these crucibles have a higher amount of zirconium in the outer part of them. It decreases towards the inside, and after a while it reaches a constant level. This concentration is higher in the interdendritic $\gamma$ constituent than in the lamellar dendritic $\alpha_{2}$. So it might be concluded that zirconium is segregated 
Table 1 Chemical analysis of samples melted in different crucibles

\begin{tabular}{|c|c|c|c|c|c|c|c|c|c|c|c|c|}
\hline $\begin{array}{l}\text { Distance fror } \\
\text { surface }(\mu \mathrm{m})\end{array}$ & 10 & 50 & 100 & 150 & 200 & 250 & 300 & 500 & 1000 & 2000 & 3000 & \\
\hline & & & & & Crucibl & e mater & rial $\mathrm{ZrO}$ & $\mathrm{O}_{2} / \mathrm{MgO}$ & & & & case \\
\hline $\begin{array}{l}\text { Constituent } \\
\alpha_{2}+\gamma\end{array}$ & $\begin{array}{l}\mathrm{Ti}(\text { at } \%) \\
\mathrm{Al}(\text { at } \%) \\
\mathrm{Zr}(\text { at } \%)\end{array}$ & $\begin{array}{c}55.2 \\
43.8 \\
0.95\end{array}$ & $\begin{array}{l}53.8 \\
45 \\
1.19\end{array}$ & $\begin{array}{l}55 \\
44 \\
0.95\end{array}$ & $\begin{array}{r}55.3 \\
43.5 \\
1.2\end{array}$ & $\begin{array}{c}55.5 \\
43.5 \\
0.96\end{array}$ & $\begin{array}{c}54.5 \\
44.5 \\
0.97\end{array}$ & $\begin{array}{c}54.4 \\
46.2 \\
1.39\end{array}$ & $\begin{array}{c}54.1 \\
45.1 \\
0.81\end{array}$ & $\begin{array}{c}55.1 \\
44.2 \\
0.77\end{array}$ & $\begin{array}{l}56.2 \\
43 \\
0.74\end{array}$ & 0.93 \\
\hline $\begin{array}{l}\text { Constituent } \\
\gamma\end{array}$ & $\begin{array}{l}\mathrm{Ti}(\mathrm{at} \%) \\
\mathrm{Al}(\mathrm{at} \%\} \\
\mathrm{Zr}(\mathrm{at} \%)\end{array}$ & $\begin{array}{c}43.1 \\
53.1 \\
3.83\end{array}$ & $\begin{array}{r}42.7 \\
53.6 \\
3.7\end{array}$ & $\begin{array}{r}42.1 \\
52.7 \\
5.1\end{array}$ & $\begin{array}{c}43 \\
52.9 \\
4\end{array}$ & $\begin{array}{r}42.7 \\
53.5 \\
3.8\end{array}$ & $\begin{array}{r}42 \\
53.6 \\
4.3 \\
\end{array}$ & $\begin{array}{c}42.4 \\
54.1 \\
3.55\end{array}$ & $\begin{array}{l}42.6 \\
54 \\
3.31\end{array}$ & $\begin{array}{c}42.8 \\
53.8 \\
3.47\end{array}$ & $\begin{array}{c}42.8 \\
54.1 \\
3.09\end{array}$ & 3.36 \\
\hline & Dew ratre & & & & Cruci & mate & rial ZrC & $\mathrm{O}_{2} / \mathrm{Y}_{2} \mathrm{O}_{3}$ & & & & \\
\hline $\begin{array}{l}\text { Constituent } \\
\alpha_{2}+\gamma\end{array}$ & $\begin{array}{l}\mathrm{Ti}(\text { at } \%) \\
\mathrm{Al}(\text { at } \%) \\
\mathrm{Zr}(\text { at } \%)\end{array}$ & $\begin{array}{l}55.8 \\
42.9 \\
1.38\end{array}$ & $\begin{array}{c}54.7 \\
44.1 \\
1.24\end{array}$ & $\begin{array}{c}54.6 \\
44.3 \\
1.14\end{array}$ & $\begin{array}{c}54.5 \\
44.5 \\
1.12\end{array}$ & $\begin{array}{c}52.2 \\
46.1 \\
1.68\end{array}$ & $\begin{array}{l}55.6 \\
43.7 \\
0.75\end{array}$ & $\begin{array}{l}57 \\
42.4 \\
0.42\end{array}$ & $\begin{array}{c}56.9 \\
42.5 \\
0.59\end{array}$ & $\begin{array}{c}55.9 \\
43.7 \\
0.74\end{array}$ & $\begin{array}{c}55.6 \\
43.8 \\
0.52\end{array}$ & 0.57 \\
\hline $\begin{array}{l}\text { Constituent } \\
\gamma\end{array}$ & $\begin{array}{l}\text { Ti (at\%) } \\
\text { Al (at } \%) \\
\text { Zr (at } \%)\end{array}$ & $\begin{array}{r}40.2 \\
52.9 \\
6.8 \\
\end{array}$ & $\begin{array}{r}40.7 \\
52.9 \\
6.2 \\
\end{array}$ & $\begin{array}{r}40.8 \\
52.5 \\
6.2 \\
\end{array}$ & $\begin{array}{l}41 \\
53.2 \\
5.7\end{array}$ & $\begin{array}{c}41.2 \\
53 \\
5.5 \\
\end{array}$ & $\begin{array}{r}40.3 \\
53.0 \\
6.7\end{array}$ & $\begin{array}{r}41.2 \\
52.8 \\
5.8\end{array}$ & $\begin{array}{r}41.7 \\
53.1 \\
5.1\end{array}$ & $\begin{array}{c}42.1 \\
52.8 \\
4.91\end{array}$ & $\begin{array}{c}43.5 \\
52.5 \\
4.05\end{array}$ & $\begin{array}{l}4.96 \\
4.9605\end{array}$ \\
\hline & & & & & Cruc & le mate & erial $\mathrm{Zr}$ & $\mathrm{rO}_{2} / \mathrm{CaO}$ & & & & \\
\hline $\begin{array}{l}\text { Constituent } \\
\alpha_{2}+\gamma\end{array}$ & $\begin{array}{l}\mathrm{Ti}(\text { at } \%) \\
\mathrm{Al}(\text { at } \%) \\
\mathrm{Zr}(\text { at } \%)\end{array}$ & $\begin{array}{c}53.4 \\
46.1 \\
0.57\end{array}$ & $\begin{array}{c}52.5 \\
46.8 \\
0.65\end{array}$ & $\begin{array}{c}52.2 \\
47.2 \\
0.45\end{array}$ & $\begin{array}{c}52.2 \\
47.2 \\
0.54\end{array}$ & $\begin{array}{l}52 \\
47.3 \\
0.52\end{array}$ & $\begin{array}{l}52 \\
47.4 \\
0.53\end{array}$ & $\begin{array}{c}52.1 \\
47.7 \\
0.25\end{array}$ & $\begin{array}{c}51.9 \\
47.9 \\
0.24\end{array}$ & $\begin{array}{c}51.9 \\
47.8 \\
0.18\end{array}$ & $\begin{array}{l}51.7 \\
48 \\
0.17\end{array}$ & 0.27 \\
\hline $\begin{array}{l}\text { Constituent } \\
\gamma\end{array}$ & $\begin{array}{l}\mathrm{Ti}(\mathrm{at} \%) \\
\mathrm{Al}(\mathrm{at} \%) \\
\mathrm{Zr}(\mathrm{at} \%)\end{array}$ & $\begin{array}{l}43.4 \\
53.5 \\
2.97\end{array}$ & $\begin{array}{c}43.64 \\
53.15 \\
3.33\end{array}$ & $\begin{array}{l}43.5 \\
54.1 \\
2.37\end{array}$ & $\begin{array}{l}44 \\
54 \\
1.88\end{array}$ & $\begin{array}{c}44.2 \\
54.6 \\
1.23\end{array}$ & $\begin{array}{c}44.1 \\
54.8 \\
1.02\end{array}$ & $\begin{array}{r}44.2 \\
54.9 \\
0.9\end{array}$ & $\begin{array}{r}44.5 \\
54.7 \\
0.8\end{array}$ & $\begin{array}{c}45.6 \\
53.5 \\
0.86\end{array}$ & $\begin{array}{c}45.5 \\
53.5 \\
0.83\end{array}$ & 0.88 \\
\hline & & & & & $\mathrm{Cr}$ & le & erial & $\mathrm{CaO}$ & & & & \\
\hline $\begin{array}{l}\text { Constituent } \\
\alpha_{2}+\gamma\end{array}$ & $\begin{array}{l}\mathrm{Ti}(\mathrm{at} \%) \\
\mathrm{Al}(\mathrm{at} \%) \\
\mathrm{Ca}(\mathrm{at} \%)\end{array}$ & $\begin{array}{l}50.2 \\
49.8\end{array}$ & $\begin{array}{l}51.7 \\
48.3 \\
\text { Belo }\end{array}$ & low the & $\begin{array}{c}52.6 \\
47.4 \\
\text { e equi }\end{array}$ & nent & $\begin{array}{l}51.9 \\
48.1 \\
\text { detectio }\end{array}$ & $\begin{array}{l}52 \\
48 \\
\text { limit }\end{array}$ & $\begin{array}{l}52.5 \\
47.5\end{array}$ & $\begin{array}{l}53 \\
47\end{array}$ & $\begin{array}{l}53 \\
47\end{array}$ & \\
\hline $\begin{array}{l}\text { Constituent } \\
\gamma\end{array}$ & $\begin{array}{l}\mathrm{Ti}(\mathrm{at} \%) \\
\mathrm{Al}(\mathrm{at} \%) \\
\mathrm{Ca}(\mathrm{at} \%)\end{array}$ & $\begin{array}{r}44.4 \\
55.5 \\
0.1\end{array}$ & $\begin{array}{l}46.5 \\
53.5 \\
\text { Belo }\end{array}$ & low the & $\begin{array}{l}45.8 \\
54.2 \\
\text { e equip }\end{array}$ & ent d & $\begin{array}{c}45.9 \\
54.1 \\
\text { letectio }\end{array}$ & $\begin{array}{l}47 \\
53 \\
\text { n limit }\end{array}$ & $\begin{array}{l}45.8 \\
54.2\end{array}$ & $\begin{array}{l}47 \\
53\end{array}$ & $\begin{array}{l}46 \\
54\end{array}$ & \\
\hline
\end{tabular}

0.1 Below the equipment detection limit

Crucible material Cast part- $\mathrm{ZrO}_{2} \mathrm{Y}_{2} \mathrm{O}_{3}$ crucible-graphite permanent mould

\begin{tabular}{lcccccc}
\cline { 2 - 6 } Constituent & $\mathrm{Ti}$ (at\%) & 54.8 & 54.6 & 54.9 & 55 \\
$\alpha_{2}+\gamma$ & $\mathrm{Al}$ (at\%) & 45 & 45.1 & 44.9 & 44.7 \\
& $\mathrm{Zr}$ (at\%) & 0.2 & 0.23 & 0.2 & 0.25 \\
& $\mathrm{Ti}$ (at\%) & 44.5 & 44.8 & 44.2 & \\
Constituent & $\mathrm{Al}$ (at\%) & 54.3 & 54.2 & 54.7 & 54.9 \\
$\gamma$ & $\mathrm{Zr}$ (at\%) & 1.16 & 1.03 & 1.1 & 1.1
\end{tabular}

into the interdendritic melt. during solidification, and that it dissolves preferentially there.

The gradient segregation profiles are lower in samples processed in $\mathrm{ZrO}_{2} / \mathrm{MgO}$ crucibles than in the others, which might reveal lower zirconium dissolution during the solid cooling stage.

Among all zirconia crucibles tested, those stabilized with $\mathrm{CaO}$ presented the lowest levels of zirconium absorption (see Figure 4 and Table 1).

It was not possible to evaluate the contamination of the melt with yttrium, calcium or magnesium, as its content was lower than the detection level of $0.1 \%$.

Concerning the microhardness, as mentioned in other references, there is a decrease from the outside towards the inside of the samples. There is a thin outside layer, which is harder than the average, and named alpha-case. The thickness of this layer ( 300 to $600 \mu \mathrm{m}$ ) (Table 2) is of the same order of magnitude observed by others for pure titanium castings. ${ }^{2,16,17}$ This hardness profile has about the same shape in both microconstituents 


\section{$\% Z r$ - Constituent y}

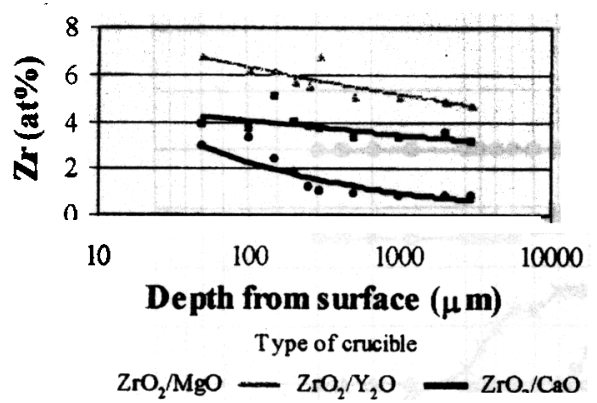

\section{$\% Z r$ - Constituent $\alpha_{2}+\gamma$}

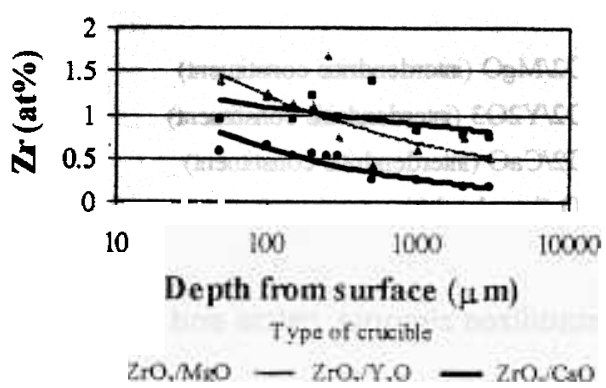

Fig. 4 Variation of $\% \mathrm{Zr}$ with the distance from the crucible wall

but dendritic $\alpha_{2}$ is always harder than $\gamma$, for all the samples.

The microhardness profile has two different types of behaviour: near the surface there is a rapid decrease of microhardness with the increase in distance from the sample/refractory interface. The inner part of the sample has a near constant hardness value, as shown in Figure 5, which suggests that there is a constant level of contamination resulting from the period when the metal was in the molten state. The outside profile suggests that it resulted from the metal-ceramic reaction during the cooling of the sample, in the solid state.

The microhardness inside the samples processed in $\mathrm{ZrO}_{2} / \mathrm{CaO}$ is of the same magnitude as that mentioned in bibliographic references for the $\gamma$ constituent of binary
TiAl alloys, as suggested in Figure 6. As previously mentioned. the $\alpha_{2}$ hardness is slightly higher than those values suggested for the average composition of this microconstituent. Samples processed in $\mathrm{ZrO}_{2} / \mathrm{Y}_{2} \mathrm{O}_{3}$ crucibles have a microhardness slightly higher than that referred to in the bibliography for the $\gamma$ microconstituent. There are no references to the microhardness of $\alpha_{2}$ for the chemical composition of these samples.

However, according to Figure 6 and considering that the reference profile does not change too much for aluminium contents between 42 and $46 \%$ (at\%), the microhardness for $\alpha_{2}$ should not be higher than the above mentioned maximum.

For samples processed in $\mathrm{ZrO}_{2} / \mathrm{MgO}$ crucibles, the microhardness is higher than values mentioned in the references, in both microconstituents.

It is considered that the hardness increase is an outcome of contamination with residual elements. With the technique used, the only residual element found was Zr. If zirconium is present in the alloy, it comes from the reduction of zirconia by elements in the melt. According to the Ellingham diagram for the formation of oxides, the reduction of zirconia by aluminium with formation of $\mathrm{Al}_{2} \mathrm{O}_{3}$, is possible.

If zirconium is present. oxygen should also be present. but it was not possible to evaluate this with the technical means available. However there is some structural evidence of its presence. since some aluminium oxides were found inside the $\lambda$ phase, as suggested by the microstructure in Figure 7 and its EDS spectrum in Figure 8.

It is thought that when zirconium makes a solid solution with titanium it increases Ti hardness. ${ }^{16.17}$ Oxygen increases hardness to a higher degree, because it makes an interstitial solid solution with titanium.

In our samples there is not a direct relationship between the amount of zirconium in the microstructure and microhardness. However, they present the same type of profile, that is, both decrease from the outside towards the inside of the sample, and both profiles became constant after a certain distance from the outside. Taking Figures 9,10 and 11 into consideration, it should be noticed that the profiles do not overlap.

In the samples processed in $\mathrm{ZrO}_{2} / \mathrm{Y}_{2} \mathrm{O}_{3}$ crucibles, the microhardness still decreases after zirconium reaches a constant level in both constituents within the sample. In

Table 2 Microhardness and extension of the "Alpha-case" in samples melted and soldified in stabilized zirconia and calcia crucibles, and in a sample poured in a graphite mould

\begin{tabular}{|c|c|c|c|c|c|c|c|}
\hline $\begin{array}{l}\text { Crucible } \\
\text { material }\end{array}$ & \multicolumn{2}{|c|}{$\begin{array}{c}\text { Vickers hardness } \\
\text { on "alpha-case" } \\
\text { (max) }\end{array}$} & \multicolumn{2}{|c|}{$\begin{array}{l}\text { Vickers hardness } \\
\text { on bulk }\end{array}$} & \multicolumn{2}{|c|}{$\begin{array}{c}\text { Zr content } \\
\text { on bulk (at } \%)\end{array}$} & $\begin{array}{l}\text { Extension of } \\
\text { the 'alpha-case' } \\
(\mu \mathrm{m})\end{array}$ \\
\hline $\begin{array}{l}\mathrm{ZrO}_{2}(\mathrm{MgO} \text { stab. }) \\
\mathrm{ZrO}_{2}\left(\mathrm{Y}_{2} \mathrm{O}_{3} \text { stab. }\right) \\
\mathrm{ZrO}_{2}\left(\mathrm{Y}_{2} \mathrm{O}_{3} \text { stab. }\right)\end{array}$ & $\begin{array}{c}\alpha_{2}+\gamma \\
644 \\
580\end{array}$ & $\begin{array}{c}\gamma \\
594 \\
412\end{array}$ & $\begin{array}{c}\alpha_{2}+\gamma \\
549 \\
473\end{array}$ & $\begin{array}{l}\gamma \\
473 \\
313\end{array}$ & $\begin{array}{c}\alpha_{2}+\gamma \\
0.93 \\
0.57\end{array}$ & $\begin{array}{c}\gamma \\
3.36 \\
4.96\end{array}$ & $\begin{array}{l}400 \\
600\end{array}$ \\
\hline $\begin{array}{l}\text { Cast part } \\
\mathrm{ZrO}_{2}(\mathrm{CaO} \text { stab.) } \\
\mathrm{CaO}\end{array}$ & $\begin{array}{l}473 \\
341\end{array}$ & $\begin{array}{l}321 \\
303\end{array}$ & $\begin{array}{l}350 \\
351 \\
313\end{array}$ & $\begin{array}{l}300 \\
257 \\
280\end{array}$ & $\begin{array}{l}0.22 \\
0.27 \\
-\end{array}$ & $\begin{array}{l}1.1 \\
0.88 \\
-\end{array}$ & $\begin{array}{l}300 \\
200\end{array}$ \\
\hline
\end{tabular}

stab. $=$ stabilized 


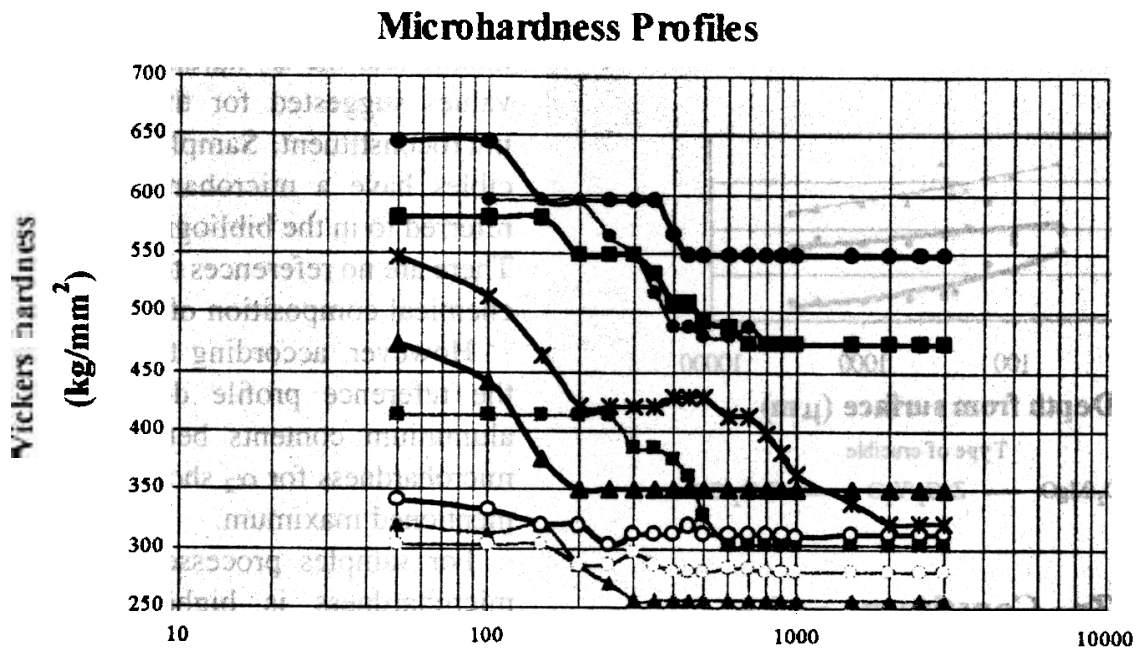

Depth from surface $(\mu \mathrm{m})$
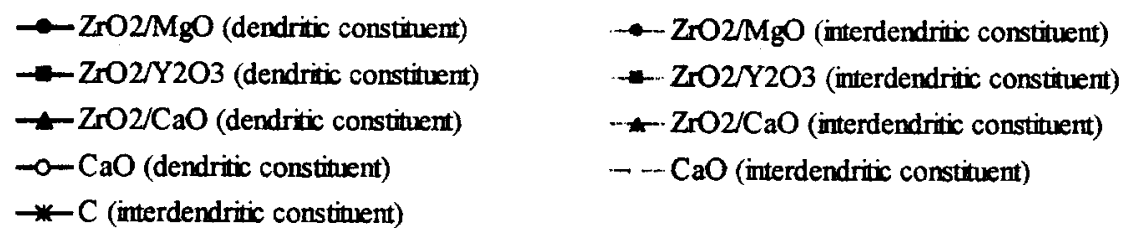

Fig. 5 Microhardness profiles of samples melted and cooled in stabilized zirconia, calcia and graphite crucibles

samples processed in $\mathrm{ZrO}_{2} / \mathrm{Y}_{2} \mathrm{O}_{3}$ this type of behaviour is even more pronounced. In samples made in $\mathrm{ZrO}_{2} / \mathrm{CaO}$ crucibles, the profiles of microhardness and zirconium are the same for $\gamma$, but for $\alpha_{2}$, zirconium content decreases after microhardness assumes a constant value. However, the most obvious conclusion is that zirconium is not the only or the most important element to affect hardness.

In samples where the stabilizer was $\mathrm{Y}_{2} \mathrm{O}_{3}$, the alphacase is about $600 \mu \mathrm{m}$ thick and the $\mathrm{Zr}$ content assumes a constant value beyond $300 \mu \mathrm{m}$. Taking into account the reduction of zirconium oxide, the only remaining factor is the possible presence of oxygen, considering that this

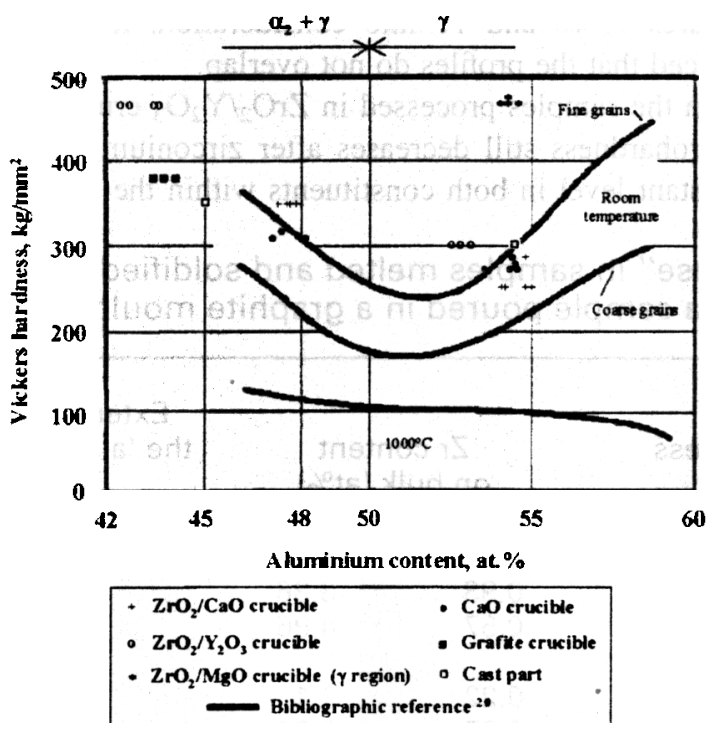

Fig. 6 Microhardness comparison of present results using different crucible refractory materials with previous published data 20 element has a much higher diffusion coefficient in titanium. ${ }^{17}$ When the soluble zirconium content is lower than 0.5 at $\%$, its influence over microhardness seems to be negligible, as can be seen in samples obtained in $\mathrm{CaO}$ stabilized zirconia crucibles. In these samples there would also be the influence of oxygen, since the same zirconium content at different distances from surface $(0.53 \%$ at $150 \mu \mathrm{m}$ and $0.57 \%$ at $50 \mu \mathrm{m}$ ) corresponds to different hardness values -376 and $473 \mathrm{HV}$.

The smallest alpha-case using zirconia crucibles, was observed in those stabilized with $\mathrm{CaO}$, followed by those stabilized with $\mathrm{MgO}$ and finally those with $\mathrm{Y}_{2} \mathrm{O}_{3}$. Table 2 presents microhardness values and $\mathrm{Zr}$ contents in the base metal and in the "alpha-case", along with its dimension in the other two types of zirconia crucibles.

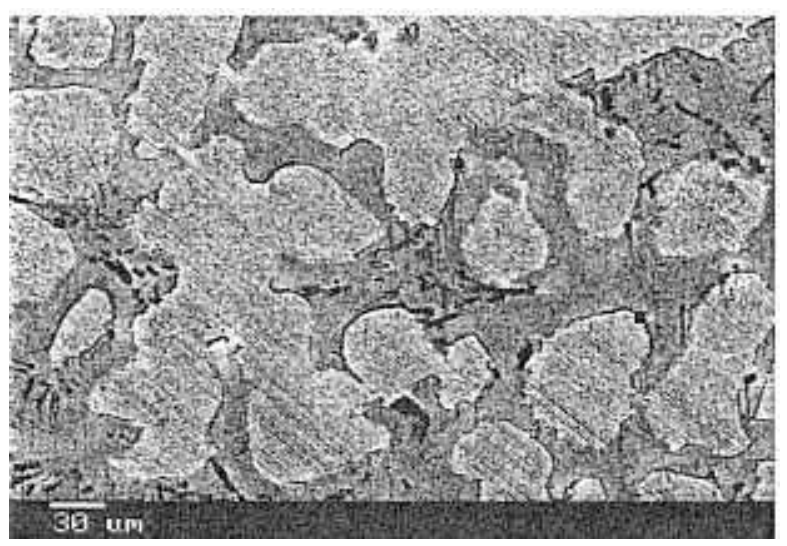

Fig. 7 Aluminium oxides in the interdendritic microconstituent (black dots) of a sample obtained in a magnesia stabilized zirconia crucible 


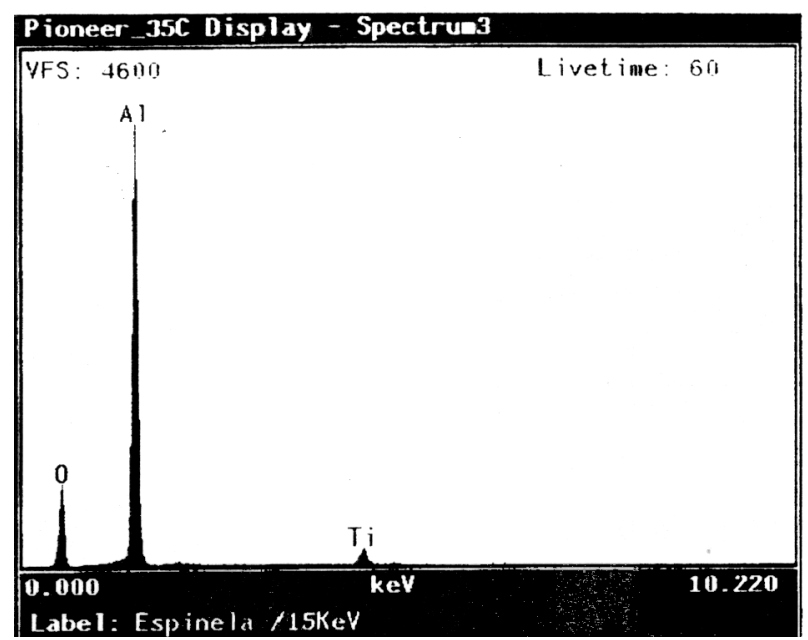

Fig. 8 EDS spectrum of a black dot present in the interdendritic microconstituent of a sample obtained in a magnesia stabilized zirconia crucible

\section{$\mathrm{CaO}$ crucibles}

The $\mathrm{CaO}$ crucibles produced the best results. As can be seen in Figure 5 and Table 2, samples presented the lowest microhardness, both in the base metal and in the alpha-case. They also present the lowest alpha-case of all produced samples $-200 \mu \mathrm{m}$.

The samples do not show a calcium concentration higher than the detection level of $0.1 \%$, free or as an alloy solution. This may confirm a high stability in this refractory and a low solubility of calcium in this kind of alloy.

The microhardness values are of the same order as those mentioned in some references, for surface distances higher than $200 \mu \mathrm{m}$, although in the surface layer there are some values a little higher (see Figure 6).

The slight hardness variation that is seen in the outer part of samples is not fully understood. Calcia is a more stable oxide than alumina or titania so there is a very small probability that the reduction of calcia might occur in this kind of melt. The introduction of oxygen seems very inlikely, because, in this situation, the overall microhardness in the interior of the sample should be higher. According to some authors, the only factor, which might increase hardness, could be a smaller grain size. ${ }^{20}$.

Calcia crucibles are very prone to thermal shock, and all of them presented small cracks after melting. Those cracks began to occur in the interface with the melt.

\section{Graphite crucibles}

As expected, the microstructures of samples that cooled inside this type of crucible are very different from those previously mentioned. Up to a distance of $2500 \mu \mathrm{m}$ from the surface, there is a constituent that is richer in aluminium (an overall composition of 60 at\% Al, 33 at $\% \mathrm{Ti}$ and 7 at $\%$ C). This constituent is very dense near the surface, increases in size when this distance increases and become less dense, as can be seen in Figure 12.

In the central part of the sample, from $2500 \mu \mathrm{m}$, the microstructure is lamellar $\alpha_{2}+\gamma$ with about 5 at $\% \mathrm{C}$ and $\lambda$ with about 3 at\% C. Those crucibles are unsuitable for processing TiAl melts due to the high carbon absorption.

\section{Samples poured into graphite moulds}

To evaluate the suitability of moulds made of machined graphite blocks, a few melts processed in $\mathrm{ZrO}_{2} / \mathrm{Y}_{2} \mathrm{O}_{3}$ crucibles have been made and cast using centrifugal casting.

As can be seen in Figure 13, there is no microhardness change in either constituent with the distance from the surface. These values tally well with those of other references, as suggested in Figure 6.

The base metal contains zirconium, with an average value content throughout the sample (see Table 1 and Figure 13), suggesting that it comes from the melting stage. The $\mathrm{Zr}$ content was about 0.2 at $\%$ in dendritic lamellar $\alpha_{2}$, and about $1 \%$ in $\gamma$ (see Table 1). These values are much smaller than those found in samples that cooled inside $\mathrm{ZrO}_{2} / \mathrm{Y}_{2} \mathrm{O}_{3}$ crucibles $(0.57$ at $\%$ and 4.96 at\% for lamellar and interdendritic constituents).

\section{$\mathrm{ZrO}_{2} / \mathrm{MgO}$ Crucible}

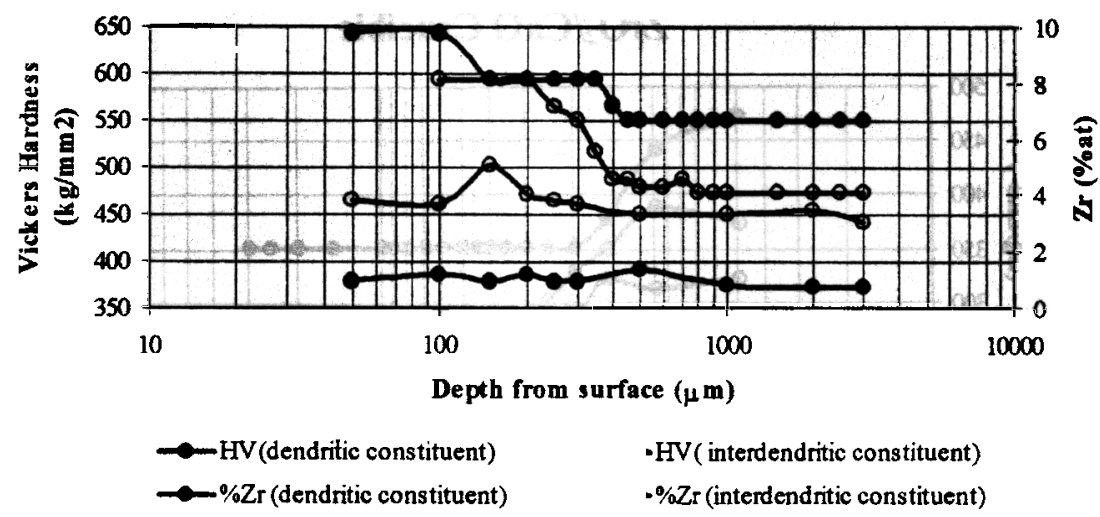

Fig. 9 Microhardness and \% $\mathrm{Zr}$ profiles in a sample melted and cooled in a magnesia stabilized zirconia crucible 


\section{$\mathrm{ZrO}_{2} / \mathrm{Y}_{2} \mathrm{O}_{3}$ Crucible}

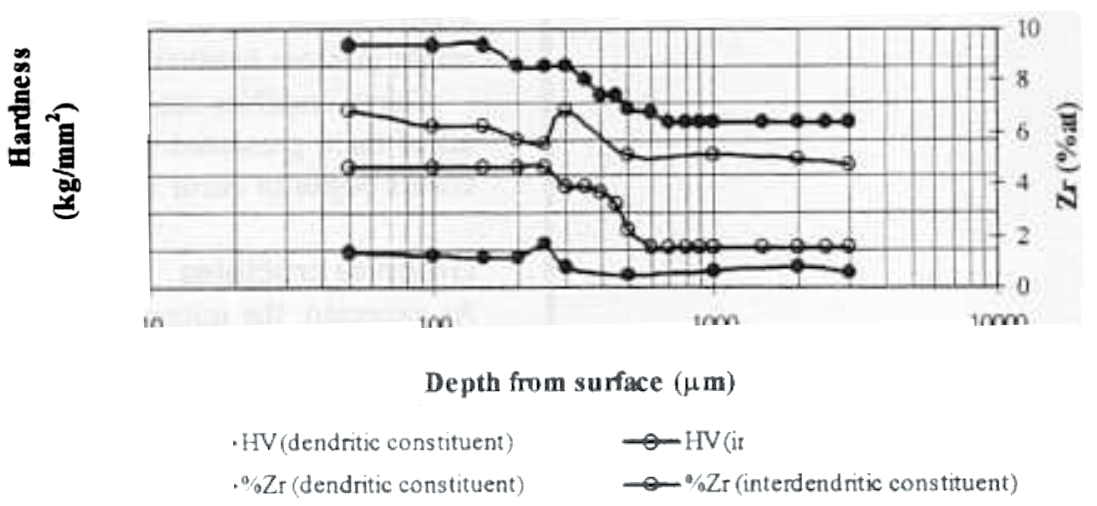

Fig. 10 Microhardness and \% Zr profiles in a sample melted and cooled in a yttria stabilized zirconia crucible

Microhardness values follow the same trend. As suggested in Table 1, Figures 10 and 13, microhardness is about $350 \mathrm{HV}$ for $\alpha_{2}$ and $300 \mathrm{HV}$ for $\gamma$. For those samples that cooled inside the crucibles, the values were $473 \mathrm{HV}$ and $313 \mathrm{HV}$.

Melt processing was the same in both situations. which permits the conclusion that the zirconium contamination in the base metal is a result of the interaction between melt and crucible during the liquid stage. The solidification time is much higher in the crucible, because the thermal conductivity of zirconia $\left(2 \mathrm{Wm}^{-1} \mathrm{~K}^{-1}\right)^{27}$ is lower than that of graphite $\left(140 \mathrm{Wm}^{-1} \mathrm{~K}^{-1}\right)^{28}$ and the crucible is hotter than the mould.

The outer layer does not present any carbon contamination. Graphite could be used as a mould material in situations where the solidification time is of the same order as those used.

\section{Conclusions}

1. In all samples melted in zirconium based crucibles. there is evidence of contamination from this element. In those processed in calcia crucibles, there is no evidence of contamination.

2. Samples that cooled inside zirconia crucibles present a decreasing contamination profile from the outside towards the inside of castings.
3. The dissolution of residual elements occurs preferentially into interdendritic $\gamma$ whereas the concentration into lamellar dendritic $\alpha_{2}$ is much smaller.

4. Microhardness decreases from the outside towards the inside of castings, with a profile that tallies with other references. The microhardness is higher in the outer alpha-case, as a result of contamination with some residual elements. Zirconium is a potential source. but because hardness and contamination profiles do not match, and assuming that it comes from a reaction of melt elements with the refractory oxide, then oxygen might also be present.

5. For each sample the $\alpha^{2}+\gamma$ microconstituent is harder than $\gamma$, although is has a lower level of zirconium contamination.

6. Microhardness profiles do not match with $\mathrm{Zr}$ segregation profiles, although they follow the same trend. This fact, together with the formation of aluminium oxide in the melts processed in $\mathrm{MgO}$ stabilized crucibles and previous work, lead us to the conclusion that oxygen might also be responsible for an increase in hardness.

7. Calcia crucibles produced the thinnest alpha-case.

8. Samples processed in $\mathrm{ZrO}_{2} / \mathrm{Y}_{2} \mathrm{O}_{3}$ and poured into permanent graphite moulds do not show evidence of carbon absorption. This was thought to be the result of a very high solidification rate.

9. Only those alloys processed in calcia or calcia

\section{$\mathrm{ZrO}_{2} / \mathrm{CaO}$ Crucible}

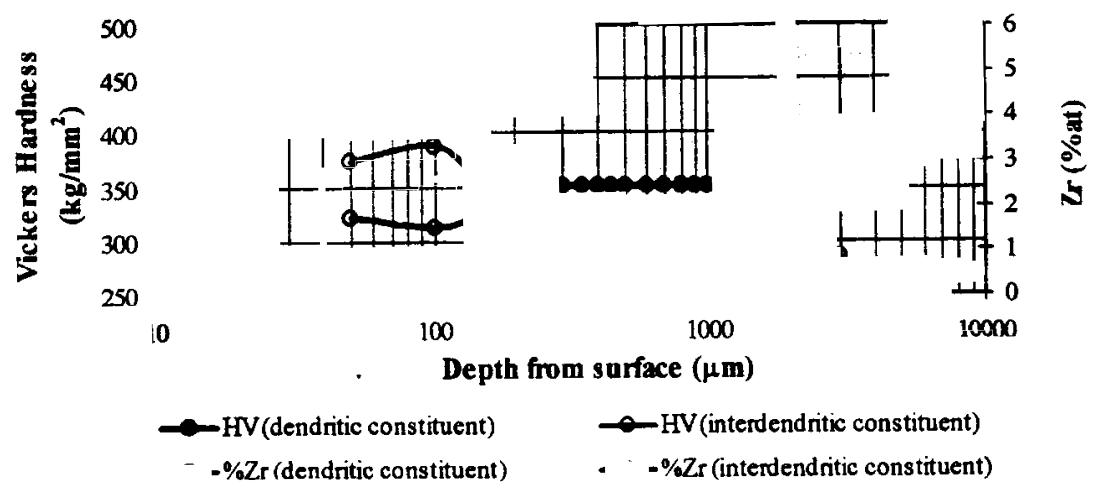

Fig. 11 Microhardness and \% Zr profiles in a sample melted and cooled in a calcia stabilized zirconia crucible 


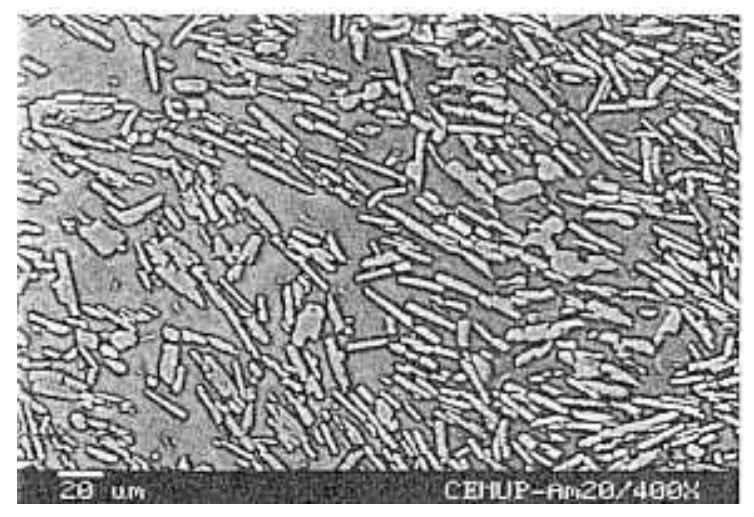

Fig. 12 Microstructure of a sample melted and cooled in a graphite crucible

stabilized zirconia crucibles presented microhardness values that tally with references.

\section{References}

1. Piwonka, T. S. - "Reactions at the Mold/Metal Interface in Investment Castings", 42nd Annual Technical Meeting of the Investment Casting Institute, publ. Investment Casting Institute, USA, 1994.

2. Schadlich-Stubenrauch. J., Sahm, P.R. - "Entwicklung einer Schleuderfeingießtechnik fur die Herstellung kleiner. dunnwandiger und filigraner Gußteile aus Titan und Titanlegierungen", Giessereiforschung, 43, nº4, 1991, p. 141-161.

3. Schadlich-Stubenrauch, J., Dieckhues, G. W., Sahm, P. R. "Investment Casting Technology for Titanium and Ti-Aluminide Near Net Shape Parts", Communicação apresentada á 27th Dedicated Conference on New and Alternative Materials for the transportation Industries, Aachen, Germany, November 1994.

4. Ott, D. - "Gießen von Titan im Dentallabor", METALL, 44, no 4, April 1990, p. 366-369.

5. Schadlich-Stubenrauch. J., Sahm, P. R., Linn, H. "Numerical Simulation of the Alpha Case as a Quality Criterion for Investment Casting of Small, Thin-Walled Titanium Parts", 6th World Conference of Titanium, Cannes, France, June 1988.

6. Bridges, P. J., Hauzeur, F. - "'Advances in the Technology of Titanium Castings', Cast Metals, 4, n'3, 1991.

7. Richerson et al. - American Patent 4040845.

8. Eastwood, L. W., Craighead, C. M. - Air Force Materials Laboratory, Report AFML-TR-6218, Part I, 1950.

9. Walters, I. R., Emblem, H. G. - American Patent 4025350 (Zirconal Processes Ltd., Bromley, UK, 1977).

10. Chapin, E. J., Friske, W. - “A Metallurgical Evaluation of Refractory Compounds for Containing Molten Titanium: Part I - Oxides", Report NRL 4447, Naval Research Laboratory, Washington, DC, 1954.

11. Walters, I. R., Emblem, H. G. - American Patent 4201594 (Zirconal Processes Ltd., Bromley, UK, 1980).

12. Chapin, E. J., Friske, W. - “A Metallurgical Evaluation of Refractory Compounds for Containing Molten Titanium: Part III - Borides and Sulfides", Report NRL 4478, Naval Research Laboratory, Washington, DC, 1955.

13. Noguchi, M., Shitaishi, M. - Patente Japonesa 1-264963, TEP K. K., Tokyo, Japan, 1989.

\section{Cast parts (grafite permanent mould)}

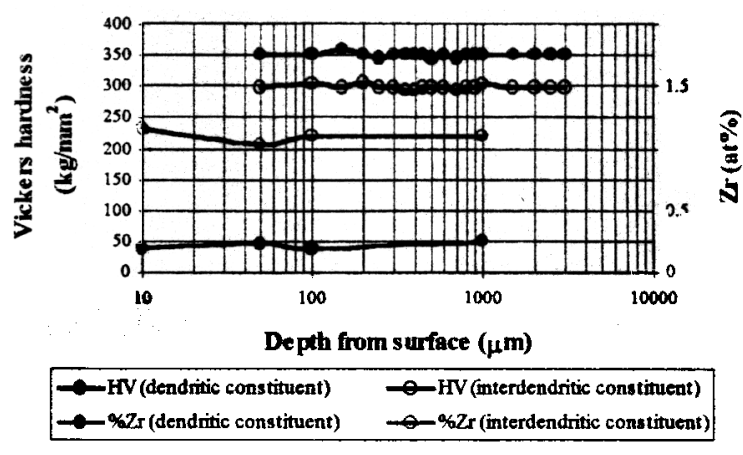

Fig. 13 Microhardness and \% $\mathrm{Zr}$ profiles in a sample melted in a yttria stabilized zirconia crucible and poured in a graphite mould

14. Elsenberg, M., Stavrolakis, J. - "Investigation of Refractories Suitable for Meiting Titanium and its Alloys", Report WADC 5391, Wright Air Development Center, WrightPatterson Air Force Base, OH, 1953.

15. Cottrell, A. H. - "Introdução á Metalurgia", $3^{\text {rd }}$ Edition, Foundation Calouste Gulbenkian, Lisboa, 1993.

16. Saha et al. - "On the Evaluation of Stability of Rare Earth Oxides as Face Coats for Investment Casting of Titanium', Metallurgical Transactions B, 21B, June 1990, p. 559-566.

17. Saha, R. L., Nandy, T. K., Misra, R. D., Jacob, K. T. "Evaluation of the reactivity of titanium with mould materials during casting", Bulletin Mater. Science, 12, n5, December 1989, p. 481-493.

18. Jones, S., Marquis, P. M., Page, B. - "The effect of impurities upon the thermal response of several proprietary casting binders", 22nd EICF Conference, 1992.

19. Kingery, W. D., Bowen, H. K., Uhlmann, D. R. - "'Introduction to Ceramics", 2nd Ed., Pub Wiley-Interscience. 1976.

20. Materials Properties Handbook - Titanium Alloys, Section VI - "Titanium Aluminides", ASM, June 1994.

21. Larsen, D., Govern, C. - "Advanced Investment Cast Processing of Gamma Titanium Aluminides", in "Gamma Titanium Aluminides", Ed Y-W Kim, R. Wagner, M. Tamaguchi, Publ. TMS, 1995, p. 405-414.

22. Materials Properties Handbook - Titanium Alloys, Section II - "Titanium Data Sheets", ASM. June 1994.

23. Sato, T., Yoneda, Y., Matsumoto, N. - "A New Process of Producing Titanium Alloy Castings", Transactions of the Japan Foundrymen's Society, Vol. 11, October 1992, p. 2733.

24. Sato, T., Yoneda, Y., Matsumoto, N. - "A Technique for Casting Titanium Alloys with Lime Refractory", 58th World Foundry Congress, Cracow, September 1991.

25. Sato et al. "Improvement of the Internal Soundness of Titanium Castings Prepared by Induction Melting in Lime Crucibles', Imono, 64, 1992, p. 312-317.

26. "Binary Alloys Phase Diagrams", Ed. ASM, 1987.

27. WEB page of company ZIRCOA, http://www.zircoa.com/ ceram.html

28. WEB page of the University of Sheffield, UK, http:// www.shef.ac.uk/chemistry/web-elements/nofr-heat/C.html

(Received 7 April 1999; accepted 22 November 1999) 